\title{
Peningkatan Kompetensi Membaca Al-Qur’an Peserta didik Melalui TPQ Sekolah
}

\author{
Muhammad Munif \\ m.munifmpdi@gmail.com \\ Universitas Nurul Jadid Paiton Probolinggo
}

\begin{abstract}
Abstrak: Pembelajaran al-Qur'an kepada para peserta didik di SMP Bhakti Pertiwi Paiton Probolinggo melalui Taman Pendidikan Al-Qur'an (TPQ) sekolah merupakan salah satu cara untuk meningkatkan kompetensi siswa dalam membaca al-Qur'an. Kegiatan pembelajaran al-Qur'an di TPQ di SMP Bhakti Pertiwi Paiton meliputi tiga bagian, yaitu membaca teks secara bersama-sama I selama 10 menit, membaca teks secara individual selama 40 menit, dan membaca teks bersama-sama II selama 10 menit. Selanjutnya, untuk mengukur kompetensi bacaan al-Qur'an siswa setelah mengikuti proses pembelajaran di TPQ sekolah, guru melakukan evaluasi. Penelitian ini menggunakan pendekatan kualitatif, dengan fokus penelitian (1) Upaya yang dilakukan oleh Lembaga Pendidikan SMP Bhakti Pertiwi untuk meningkatkan kemampuan membaca al-Qur'an peserta didik SMP Bhakti Pertiwi Paiton Probolinggo, (2) Proses pembelajaran membaca al-Qur'an di TPQ SMP Bhakti Pertiwi Paiton Probolinggo, (3) Hasil pembelajaran al-Qur'an di TPQ SMP Bhakti Pertiwi Paiton Probolinggo. Hasil penelitian ini menunjukkan bahwa setelah program ini dilaksanakan, para siswa mengalami peningkatan kompetensinya dalam membaca al-Qur'an. Para siswa dapat membaca al-Qur' an dengan tartil dan benar.
\end{abstract}

Kata Kunci: Kompetensi, Al-Qur'an, TPQ 


\section{Pendahuluan}

Pendidikan Agama Islam (PAI) dalam pelaksanaannya di lapangan hingga sekarang ini masih tetap banyak kendala dan kekurangan yang terus menerus perlu dicarikan jalan keluar (solusi) dan penyempurnaannya. Kritik dari berbagai kalangan tentang pelaksanaan PAI bisa dibedakan dari kalangan guru/dosen dan masyarakat. Para guru/dosen umumnya mengeluhkan alokasi jam pelajaran/kuliah yang sangat minim, terbatasnya sarana prasarana dan kurangnya dukungan dari keluarga. Kritik dari masyarakat terutama tertuju pada banyaknya lulusan sekolah umum yang belum bisa membaca Al Qur'an dengan kriteria tartil dan benar, apalagi menulis huruf Al Qur'an. (Khozin, 2006:233). Membaca al-Qur'an dengan tartil dan benar merupakan kompetensi dasar (KD) dalam pembelajaran PAI di Sekolah. Kompetensi diartikan sebagai pengetahuan, keterampilan dan kemampuan yang dikuasai oleh seseorang yang telah menjadi bagian dari dirinya, sehingga ia dapat melakukan kemampuan-kemampuan kognitif, afektif dan psikomotorik dengan sebaik-baiknya. (Susilo, 2007:98).

Fakta yang terjadi ternyata banyak peserta didik yang beragama Islam tidak mampu membaca al-Qur'an dengan benar meskipun mereka mengaku telah belajar membaca Al Qur'an sejak kecil dari orang tua dan para ustadz/ustadzah dimana mereka tinggal. Banyak siswa yang tidak paham tentang makharijul huruf (cara mengucapkan huruf-huruf hija'iyah) dan sifatul huruf hija'iyah (sifat-sifat huruf hija'iyah) serta belum memahami tajwid.

Sekolah Menengah Pertama Bhakti Pertiwi kecamatan Paiton kabupaten Probolinggo merupakan lembaga pendidikan yang berupaya semaksimal mungkin untuk memberikan layanan pendidikan kepada para peserta didiknya. Untuk membantu siswa agar memiliki kompetensi dalam aspek membaca al-Qur'an, sekolah mewajibkan semua peserta didiknya untuk mengikuti program pembelajaran al-Qur'an dengan memberikan fasilitas sebuah Taman Pendidikan Alqur'an (TPQ), yang berlokasi di sekolah. Dalam mensukseskan program ini sekolah merekrut beberapa guru Al Qur'an (ustadz-ustadzah) yang telah memiliki kompetensi dalam aspek bacaan Al Quran.

Pada proses pembelajaran al-Qur'an dengan menggunakan metode Qiroati, para peserta didik mengikuti pembelajaran al-Qur'an mulai dari kelas jilid per jilid, sampai pada kelas al-Qur'an. Peserta didik yang telah menyelesaikan semua tahapan dan materi pembelajaran Al Qur'an metode Qiro'ati dapat mengikuti tes tahap akhir di tingkat cabang Probolinggo. Peserta yang dinyatakan lulus berhak mendapatkan syahadah (sertifikat) yang dikeluarkan oleh 
Koordinator Cabang Qiro'ati Probolinggo.

\section{Konsepsi Pembelajaran al-Qur'an}

Dalam dunia pendidikan sering kita dengar kata pembelajaran. Pembelajaran adalah usaha-usaha yang sistematis dan terencana agar terjadi proses belajar dalam diri siswa (Sadiman, 2006:7). Dalam pembelajaran, guru berfungsi sebagai fasilitator, yang memanage/mengatur berbagai sumber untuk dipelajari siswa. (Wina Sanjaya, 2006:78). Proses pembelajaran pada hakekatnya merupakan pelayanan yang khusus diperuntukkan bagi para siswa yang terlibat dalam pembelajaran. (Tohirin, 2005:17). Guru mendesain metode pembelajaran menggunakan teori pendidikan. (Syagala, 2005:62).

Kegiatan tersebut merupakan pelayanan dan proses interaksi antara guru dan siswa dalam satu lingkungan belajar. Peserta didik memegang peranan utama dan lebih aktif, sedangkan pendidik hanya sebagai fasilitator. Dalam merekayasa pembelajaran yang berdasarkan kurikulum, guru menggunakan asas atau teori pendidikan (Islam, 2017). Posisi siswa yang dominan tersebut diharapkan akan menumbuhkan inovasi dan kreatifitas dalam pembelajaran.

Secara harfiah, Al Qur'an adalah "bacaan" atau yang dibaca. Pengertian ini sejalan dengan maksud diturunkannya al-Qur'an agar dibaca sebagaimana firman Allah dalam Surat Al Alaq ayat 1, untuk dipahami dan diamalkan isi kandungannya dalam kehidupan sehari-hari. (Abudin Nata, 2001: 292). Abdul Wahab Khalaf (1972:23) dalam Abudin Nata mendefinisikan Al Qur'an secara istilah (terminologi) adalah firman Allah yang diturunkan kepada Rasulullah Muhammad melalui malaikat Jibril agar ia menjadi hujjah bahwa ia benar-benar Rasulullah, menjadi undang-undang atau sumber hukum bagi manusia, memberi petunjuk kepada mereka dan menjadi sarana pendekatan diri, dan ibadah kepada Allah dengan jalan membacanya.

Dengan demikian pembelajaran Al Qur'an dapat diartikan sebuah kegiatan yang dirancang oleh guru kepada siswa untuk mempelajari dan memperoleh suatu kemampuan, misalnya kemampuan membaca firman-firman Allah (Al Qur'an) dengan tartil dan benar. Kegiatan tersebut dapat direalisasikan melalui sarana Taman Pendidikan Al Qur'an (TPQ) yang diselenggarakan di sekolah-sekolah. 


\section{Pembelajaran al-Qur'an Metode Qiroati}

Al Qur'an merupakan mu'jizat terbesar yang diberikan oleh Allah kepada Rasulullah SAW. Mempelajari serta mengamalkannya merupakan kewajiban kita umat muslim. Pendekatan terbaik dalam mempelajari Al Qur'an adalah Tallaqi dan Musyafahah, yaitu berhadapan langsung antara guru dengan murid, seperti yang dilakukan oleh malaikat Jibril dengan Rasulullah SAW ketika pertama kali menerima wahyu.

Metode Qiro'ati adalah salah satu metode pembelajaran Al Qur'an praktis yang mulai dikenalkan pada tahun 1963 di Semarang Jawa Tengah. Kaidah ini dikenalkan oleh guru Al Qur'an yang bernama KH. Dahlan Salim Zarkasyi. Pada awalnya terdiri dari 10 jilid, kemudian diringkas menjadi 6 jilid untuk usia Taman Kanak-kanak (TK), 4 jilid untuk usia Sekolah Dasar (SD), 3 jilid untuk usia SMP dan SMA, 2 jilid untuk usia mahasiswa. Selain itu ada buku untuk mempelajari ghorib dan tajwid.

Seorang pengajar Qiro'ati harus melalui tahap-tahap antara lain adalah pembinaan calon guru, tashih guru, pembekalan metodologi, sampai dengan PPL. Hal ini dimaksudkan agar guru Qiro'ati mengajar sesuai kaidah ilmu tajwid dan billisanil 'Aroby, karena prinsip Qiro'ati adalah "Jangan wariskan yang salah karena yang benar itu mudah". KH. Dahlan Salim Zarkasyi berwasiat bahwa guru al-Qur'an harus memiliki beberapa kriteria antara lain sabar, ikhlas, istiqamah (rutin) tadarus al-Qur'an dan istiqamah mengerjakan shalat sunah tahajjud. (Vianata, 2007).

Metode membaca Al Qur'an Qiro'ati merupakan cara membaca al-Qur'an yang langsung tanpa di-eja, dengan membiasakan bacaan tartil sesuai ilmu tajwid. Tokoh penting dan penemu metode pembelajaran al-Qur'an Qiro'ati adalah KH. Dahlan Salim Zarkasyi. Pembelajaran ini mempunyai ciri-ciri sebagai berikut : Langsung membaca secara mudah bacaan-bacaan yang bertajwid. Pelajaran diberikan secara bertahap dari yang paling mudah sesuai dengan kaidah dan tahapan belajar membaca al-Qur'an. Menerapkan sistem belajar secara tuntas (Mastery Learning). Pelajaran yang diberikan selalu diulang-ulang dengan memperbanyak latihan/drill. Post test selalu diadakan setiap pertemuan.

Penerapan kegiatan belajar mengajar metode Qiroati di TPQ meliputi fase-fase/tahapan tahapan sebagai berikut:

Tahap I : Sosialisasi, pada tahap ini ustadz menjelaskan kompetensi dasar (KD) sesuai dengan pokok bahasan. 
Tahap II : Terpusat, guru memberi contoh beberapa baris atau kata, santri menyimak, menirukan dan meneruskan seluruh halaman tanpa diberi contoh guru. Pada tahap ini harus mengupayakan bahwa seluruh siswa memperhatikan penjelasan guru dan aktif mengikuti petunjuk guru.

Tahap III : Kegiatan terpimpin, guru memberikan komando dan aba-aba/ketukan, siswa membaca tanpa diberi contoh oleh guru, kecuali jika bacaan kurang tepat. Pada tahap ini guru memperhatikan siswa satu persatu untuk melihat apakah siswa aktif membaca atau tidak.

Tahap IV : Semi klasikal, santri membaca sendiri secara kelompok kecil, kelompok kecil lain menyimak/menirukan. Kelompok kecil didasarkan pada jenis kelamin, barisan tempat duduk atau lainnya.

Tahap V : Kegiatan individu, tiap siswa membaca sendiri secara bergantian sesuai kondisi.

Prinsip-prinsip Pembelajaran al-Qur'an Metode Qiro'ati yang harus diterapkan kepada para santri (peserta didik) meliputi :

Dak-Tun (tidak menuntun), dalam mengajarkan Qiro'ati guru tidak boleh banyak menuntun, guru hanya menerangkan pokok pelajaran saja dan memberi contoh bacaan yang benar satu atau dua baris.

Ti-Was-Gas (teliti, waspada, tegas), dalam memberi contoh harus teliti dan benar, saat menyimak juga harus teliti dan waspada, demikian juga pada saat penentuan kenaikan siswa pada halaman atau jilid berikutnya harus tegas. (Thariq, 2007).

\section{Proses dan Hasil Pembelajaran Al-Qur'an di TPQ SMP Bhakti Pertiwi}

Proses awal dari pembelajaran al-Qur'an metode Qiroati di TPQ SMP Bhakti Pertiwi Paiton Probolinggo dimulai dengan inisiasi kepala sekolah merekrut beberapa guru al-Qur'an (ustadz-ustadzah) yang telah memiliki kompetensi dalam aspek bacaan al-Quran dengan tartil dan benar. Para guru al-Qur'an ini telah melalui pembinaan dan tashih (tes uji kelayakan) serta telah memiliki syahadah, yakni sertifikat sebagai guru al-Qur'an metode Qiro'ati. Adapun guru yang di rekrut berasal dari guru pendidikan agama Islam yang memang telah mengajar di sekolah tersebut, ada juga yang berasal dari luar sekolah. Proses pembelajaran Al Qur'an kepada para peserta didik melalui Taman Pendidikan Al Qur'an (TPQ) SMP Bhakti Pertiwi dimulai pukul 06.30 sampai pukul 07.45 WIB.

Kegiatan pembelajaran kepada para peserta didik diawali dengan berbaris di halaman 
sekolah untuk bersama-sama membaca surat-surat pendek dan do'a sehari-hari dipandu oleh seorang ustadz, dengan alokasi waktu sekitar 10 menit, mulai pukul 06.30 sampai 06.40 WIB. Tujuan dari kegiatan awal ini adalah supaya para peserta didik dapat menghafalnya dan membiasakan diri untuk membaca do'a setiap mereka melakukan kegiatan. Adapun surat-surat pendek yang dibaca adalah surat ad-Dzuha, al-Insyirah, at-Thin, al-'Alaq, al-Qadar, al-Bayyinah, al-Zilzal, al-'Adiyah, al-Qari'ah, al-Takatsur, al- 'Ashr, al-Humazah, al-Fil, al-Qurays, al-Ma'un, al-Kautsar, al-Kafirun, an-Nashr, al-Lahab, al-Ikhlash, al-Falaq, al-Nas. Do'a-doa yang dibaca meliputi do'a makan, sesudah makan, tidur, bangun tidur, berpakaian, bepergian, bercermin, do'a katika mendapat ni'mat, ketika mendapat musibah, do'a kepada orang tua, masuk masjid, keluar masjid, masuk kakus, keluar kakus dan sebagainya.

Setelah kegiatan ini selesai, mereka masuk ke kelas masing-masing sesuai dengan penggolongan tingkat kemampuan baca al-Qur'an paserta didik. Kelas-kelas yang ada di TPQ SMP Bhakti Pertiwi ini meliputi : kelas jilid 1, jilid 2A dan 2B, jilid 3A dan 3B, 4A dan 4B, 5A dan 5B, juz 27, jilid 6, kelas Al Quran juz 1 sampai 10, kelas juz 11 sampai 20 disebut kelas gharib, dan juz 20 sampai 30 disebut kelas tajwid.

Kegiatan pembelajaran al-Qur'an di masing-masing kelas di TPQ SMP Bhakti Pertiwi Paiton Probolinggo meliputi tiga bagian, yaitu membaca teks secara bersama-sama I selama 10 menit, membaca teks satu persatu (individual) selama 40 menit, dan membaca teks bersama-sama II 10 menit. Jadi jumlah waktu keseluruhan pembelajaran Al Qur'an di kelas sebanyak 60 menit.

\section{Membaca teks bersama-sama I}

Pada tahap ini peserta didik bersama-sama membaca buku teks sesuai dengan jilid masing-masing, ada juga beberapa kelas yang menggunakan lembar peraga yang diletakkan di depan kelas untuk dibaca oleh peserta didik secara bersama-sama. Posisi lembar peraga berada di depan kelas, berada samping kanan ustadz/ustadzah, peserta didik membunyikan bacaan yang ditunjuk oleh ustadz meraka. Alat penunjuk yang digunakan oleh ustadz terbuat dari kayu dengan ukuran panjang kira-kira setengah meter. Dalam pembelajaran ini ustadz/ustadzah menggunakan prinsip "daktun" artinya tidak boleh menuntun. Ustadz hanya menjelaskan pokok bahasan saja, selanjutnya para peserta didik secara aktif membaca secara bersama-sama sesuai dengan perintah ustadz. Apabila peserta didik membaca teks jilid atau lembar peraga salah secara berulang-ulang, ustadz mengingatkan bacaan yang salah tadi secukupnya, tidak diterangkan secara panjang lebar. Kegiatan membaca teks bersama I ini berlangsung dengan meriah karena para peserta didik 
biasanya membaca secara bersemangat dengan suara yang keras.

2. Membaca teks satu persatu.

Kegiatan ini diawali dengan pemanggilan peserta didik oleh ustadz. Peserta didik yang dipanggil tadi maju ke depan kelas dengan membawa buku teks dan duduk dengan posisi menghadap ustadz. Selanjutnya ustadz menyuruh peserta didik yang telah berada didepannya untuk membaca teks jilid atau Al Qur'an sesuai dengan nomor halaman yang harus dibaca. Nomor halaman yang harus dibaca oleh masing-masing peserta didik tidak sama, disesuaikan dengan kemampuan masing-masing peserta didik. Pada saat peserta didik membaca teks jilid, ustadz mendengarkan dengan seksama bacaan peserta didik sambil melakukan penilaian kualitas bacaan mereka. Hasil penilaian tersebut ditulis dalam buku prestasi yang dimiliki oleh masing-masing peserta didik. Dalam buku prestasi ini terdapat kolom-kolom yang berisi tanggal, nama surat Al Qur'an yang dibaca, kekurangan, ayat/halaman, nilai, paraf ustadz atau ustadzah, paraf orang tua. Sampul depan buku prestasi berwarna biru bertuliskan nama TPQ yang bersangkutan, alamat TPQ, logo metode pembelajaran Qiro'ati, nama peserta didik, nomor induk, nama orang tua, dan alamat peserta didik.

Buku prestasi ini semacam catatan perkembangan (progress report) siswa dalam proses pembelajaran al-Qur'an di TPQ SMP Bhakti Pertiwi Paiton Probolinggo. Dengan membaca buku prestasi tersebut wali siswa dapat mengikuti perkembangan kemampuan anaknya dalam belajar al-Qur'an, para orang tua dapat mengetahui anaknya sekarang ada di kelas jilid berapa, sampai halaman berapa, apa kelemahan dalam membacanya, dan berapa nilainya. Buku prestasi ini menjadi sarana komunikasi antara guru TPQ dan wali siswa, dimana wali harus menandatangani buku prestasi pada kolom tandatangan orang tua, sehingga dapat melihat langsung prestasi anaknya. Setelah selesai membaca teks jilid atau al-Qur'an dan telah dinilai kualitas bacaannya oleh ustadz, peserta didik tersebut kembali ke tempat semula, ustadz memanggil siswa lain untuk maju membaca teks seperti siswa yang telah maju sebelumnya. Bagi siswa yang belum dipanggil untuk maju, mereka membaca teks ditempat duduknya dengan suara pelan untuk mempersiapkan diri sebelum mereka dipanggil maju ke depan untuk dinilai kualitas bacaannya oleh ustadz mereka. Alokasi waktu keseluruhan yang dibutuhkan pada tahap membaca secara individu pada setiap di Taman Pendidikan al-Qur'an SMP Bhakti Pertiwi Paiton Probolinggo ini sekitar 40 menit.

3. Membaca Teks Bersama-sama II 
Setelah semua peserta didik maju untuk membaca teks jilid atau al-Qur'an, kegiatan selanjutnya adalah mambaca teks bersama-sama lagi. Prosesnya sama dengan membaca bersama-sama I, yakni ustadz posisi berdiri disamping lembar peraga sambil memegang alat penunjuk di tangan kanannya, sementara para peserta didik membunyikan bacaan yang ditunjuk oleh ustadz. Bagi kelas Al Qur'an, mereka megang Al Qur'an masing-masing untuk dibaca secara bersama-sama. Apabila ada bacaan yang salah, maka ustadz memberi aba-aba berupa ketukan dua kali sebagai tanda bahwa apa yang telah dibaca oleh peserta didik ada yang salah, misalnya bacaan tajwidnya kurang tepat, tanda waqafnya dibaca washal, panjang-pendek harakat salah, ada siswa yang salah membaca harakat, ada bacaan gharib dan musykilat yang salah dan sebagainya. Alokasi waktu membaca bersama-sama II ini sekitar 10 menit.

\section{Evaluasi}

Kegiatan evaluasi di Taman Pendidikan Al-Qur'an (TPQ) SMP Bhakti Pertiwi disebut dengan tashih. Tashih yang dilaksanakan terdiri dari tiga tashih, yaitu tashih awal masuk TPQ untuk menentukan penempatan kelas bagi siswa (kelas jilid atau al-Qur'an), tashih kenaikan halaman teks jilid/tashih kenaikan ayat al-Qur'an, dan tashih tahap akhir di Koordinator Cabang (korcab) Qiro'ati Probolinggo. Tashih awal dilaksanakan ketika mereka dinyatakan diterima secara resmi menjadi peserta didik baru SMP Bhakti Pertiwi Paiton Probolinggo. Tujuan dari penyelenggaran tashih ini adalah untuk menggolongkan para peserta didik kedalam kelas-kelas sesuai dengan kemampuan mereka dalam membaca Al Qur'an. Tashih kenaikan halaman dilaksanakan setiap pertemuan, untuk menentukan apakah peserta didik layak naik ke halaman berikutnya atau masih tetap di halaman semula karena belum mampu membaca dengan kriteria lancar, cepat, tepat dan benar (LCTB). Tashih kenaikan jilid/Al Qur'an dilaksanakan jika peserta didik telah menyelesaikan seluruh halaman teks jilid/al-Qur'an. Tujuannya untuk menentukan apakah peserta didik layak untuk naik ke jilid/juz al-Qur'an berikutnya atau masih tetap di jilid/juz semula. Tashih tahap akhir dilaksanakan pada saat peserta didik telah menyelesaikan seluruh jilid, Al Qur'an, gharib, dan tajwid. Tujuan dari tashih ini adalah untuk menentukan kelulusan.

Bagi peserta didik yang dinyatakan lulus mereka berhak mendapatkan sertifikat (syahadah) yang dikeluarkan oleh Koordinator Cabang Qiro'ati Probolinggo, sedangkan yang belum lulus dikembalikan lagi pada TPQ asal untuk kembali dibina dan diberi kesempatan untuk mengikuti tashih susulan. Komponen yang menjadi kriteria penilaian dalam evaluasi (tashih) masing-masing jilid tidak sama, sesuai dengan visi misi tiap kelas jilid dan Al Qur'an yang telah ditetapkan. 
Adapun rincian visi misi adalah sebagai berikut:

1. Jilid 1 : peserta didik mampu membedakan tempat keluarnya huruf hija'iyah (makharijul khuruf).

2. Jilid 2A : Peserta didik mampu membedakan tanda baca (harakat).

3. Jilid 2B : Peserta didik mampu membedakan bacaan panjang dan pendek.

4. Jilid 3A : Peserta didik mampu membaca dengan tepat, tidak tawalud.

5. Jilid 3B : Peserta didik mampu membedakan huruf-huruf yang mirip, misalnya hamzah dengan 'ain.

6. Jilid 4A : Peseta didik mampu membaca bacaan ikhfa'.

7. Jilid 4B : Peserta didik mampu membedakan bacaan ikhfa'.

8. Jilid 5A : Peserta didik mampu membedakan tanda-tanda waqaf.

9. Jilid 5B : Peserta didik mampu membaca bacaan idgham bilaghunah.

10. Jilid 6A : Peserta didik mampu membaca bacaan idhar.

11. Jilid 6B : Peserta didik mampu membedakan bacaan idhar.

12. Juz 1-10 : Peserta didik mampu membaca dengan tartil dan benar.

13. Juz10-20 : Peserta didik mampu membaca dengan tartil dan benar serta menguasai gharib.

14. Juz 20-30 : Peserta didik mampu membaca dengan tartil dan benar serta menguasai tajwid.

Proses pelaksanaan tashih kenaikan halaman teks jilid, kenaikan jilid/Al Qur'an, dan tashih kelulusan di tingkat koordinator Cabang Qiro'ati dapat dirinci sebagai berikut: Tashih Kenaikan Halaman Teks Jilid Evaluasi ini diadakan setiap tatap muka/pertemuan. Prosesi tashih diawali dengan pemanggilan peserta didik untuk maju menuju meja ustadz dan duduk berhadapan dengan ustadz yang membina di kelas tersebut. Peserta didik membawa buku teks jilid yang akan dibacanya, sementara ustadz menyiapkan alat yang digunakan untuk menilai kemampuan peserta didik berupa buku prestasi dan pena. Ustadz kemudian memberi perintah peserta didik untuk membaca buku teksnya. Ustadz menyimak bacaan sambil menuliskan penilaian di buku prestasi siswa tersebut. Pada saat menilai ini guru harus mempunyai prinsip teliti, waspada dan tegas (tiwasgas), pada saat peserta didik membaca buku teksnya, ustadz menyimak dengan teliti dan waspada, dan pada saat menentukan kenaikan halaman jilid, ustadz harus tegas tidak boleh ragu-ragu. 
Bagi para peserta didik yang sudah memenuhi empat syarat yaitu lancar, cepat, tepat dan benar (LCTB) maka ustadz akan memberi penilaian huruf L (lulus), dan apabila belum memenuhi syarat LCTB maka pada kolom nilai di buku prestasi peserta didik akan dituliskan haruf L- (belum lulus) dan akan diberi catatan sisi kelemahan bacaan yang menyebabkan mereka belum lulus pada kolom kekurangan di buku prestasi peserta didik yang maju tersebut.

Tashih Kenaikan Jilid Evaluasi (tashih) kenaikan jilid di uji langsung oleh kepala TPQ SMP Bhakti Pertiwi. Tashih ini merupakan ujian kenaikan dari kelas jilid tertentu ke kelas satu tingkat yang lebih tinggi. Sebagai contoh, ada peserta didik yang telah menyelesaikan seluruh halaman teks jilid 3, maka oleh ustadz yang mengajar di kelas jilid 3 tersebut akan diusulkan kepada kepala TPQ untuk di tashih kenaikan jilid menuju ke jilid 4.

Tashih diawali dengan pemberitahuan hari, tanggal dan tempat pelaksanaan tashih kepada para peserta tashih. Peserta datang pada waktu yang telah ditentukan tersebut dengan membawa buku teks jilid. Di sisi lain, kepala TPQ yang bertindak sebagai penguji mempersiapkan lembar kerja evaluasi, alat tulis, dan buku prestasi peserta tashih kenaikan jilid yang sebelumnya sudah disetorkan kepada kepala TPQ. Proses tashih dimulai dengan pengarahan dari kepala TPQ SMP Bhakti Pertiwi sebagai penguji tashih.

Langkah selanjutnya penguji melakukan pemanggilan nama peserta tashih pertama, peserta yang di panggil maju kedepan menuju meja penguji dengan posisi berhadap-hadapan dengan membawa buku teks jilid. Penguji menentukan sendiri halaman berapa yang harus dibaca oleh peserta tashih, berapa pertanyaan, dan berapa lama waktu yang dibutuhkan untuk menguji seorang peserta tashih. Halaman yang diujikan tidak harus berurutan mulai dari halaman yang lebih rendah kehalaman yang lebih tinggi, tetapi dipilih secara acak oleh penguji.

Pada saat ada peserta tes yang maju / diuji oleh kepala TPQ, peserta lain membaca buku teks jilid masing-masing dengan suara pelan untuk mempersiapkan diri sebelum mendapat giliran untuk maju. Ketika peserta tes kenaikan jilid membaca teks jilid yang telah ditentukan halaman berapa yang harus dibaca, penguji memberikan penilaian berupa catatan penting, baik berupa kata-kata maupun angka. Catatan tersebut berisi tentang lulus atau tidaknya peserta tashih.

Bagi peserta tes yang dinyatakan lulus mereka berhak untuk meneruskan kejenjang kelas jilid yang lebih atas dan bagi mereka yang belum lulus belum dapat naik jilid yang lebih atas dari jilid semula. Mereka yang belum lulus akan diberikan memo tentang sisi-sisi kelemahan yang harus diperbaiki oleh ustad yang mengajar di kelas semula. Peserta tashih yang gagal tadi 
selanjutnya akan di ikutkan tashih kenaikan jilid susulan setelah di bina lebih lanjut oleh ustadznya.

Tashih Akhir di Tingkat Cabang Qiro'ati Probolinggo Pada setiap Taman Pendidikan al-Qur'an yang memakai pembelajaran metode Qiro'ati, meraka diwajibkan untuk mentashih para peserta didiknya yang telah menyelesaikan seluruh materi kepada team penguji tashih ditingkat cabang yang berkedudukan di kabupaten/kota melaui koordinator kecamatan (korcam) masing-masing.

Materi yang diujikan sama dengan yang diajarkan di masing-masing TPQ meliputi bacaan Al Qur'an, gharib, tajwid, praktikum shalat, dan do'a sehari-hari. Sebagai bagian dari TPQ yang mengikuti metode Qiro'ati, SMP Bhakti Pertiwi juga mengirimkan peserta didik yang telah menyelesaikan seluruh materi. TPQ SMP Bhakti Pertiwi memiliki strategi khusus untuk menyiapkan peserta didiknya yang akan di ikutkan tashih di tingkat cabang Proboliggo.

Sebelum menjalani tashih akhir, mereka dibina terlebih dahulu secara intensif dalam kelas finishing, yakni kelas khusus bagi para calon peserta tashih akhir. Tujuan dari kelas finishing ini adalah untuk mempertajam kembali ingatan para calon peserta tashih akan materi-materi yang telah diselesaikan di TPQ SMP Bhakti Pertiwi, sehingga mereka pada saat tashih tidak mengalami kesulitan dan lulus.

Tahap berikutnya, para calon peserta tashih diuji cobakan untuk pra tashih di tingkat koordinator kecamatan (korcam) Paiton. Tujuannya adalah untuk mengetahui sejauh mana kemampuan para peserta tashih sebelum ditashih di tingkat cabang. Team pengujinya dari pengurus korcam Paiton. Pra tashih ini semacam try out pada siswa yang akan menjalani ujian akhir nasional (UAN) di tingkat SMP dan SMA.

Proses tashih di tingkat cabang Probolinggo tidak jauh berbeda dengan tashih kenaikan jilid. Peserta tashih yang dipanggil menghadap penguji untuk ditanya beberapa pertanyaan. Penguji menyiapkan kertas lembar kerja evaluasi dan alat tulis untuk menilai kemampuan para peserta tashih. Ketika peserta menjawab pertanyaan yang diajukan, penguji mendengarkan dan menulis nilai jawaban yang diberikan dalam kertas lembar nilai tashih. Peserta yang dinyatakan lulus berhak mendapatkan sertifikat (syahadah), sedangkan yang belum lulus akan dikembalikan lagi kepada TPQ asal untuk dibina lebih lanjut. Penguji memberi catatan-catatan yang berisi kekurangan peserta tashih yang belum lulus tersebut kepada ustadz yang membinanya di TPQ asal sebagai bahan referensi sisi mana yang harus di perbaiki. Peserta tashih yang belum lulus diberi 
kesempatan untuk mengikuti tashih ulang di koordinator cabang Qiro'ati Probolinggo.

Penyelenggaraan pembelajaran Al Qur'an kepada para peserta didik SMP Bhakti Pertiwi

melalui Taman Pendidikan Al Qur'an ternyata dapat meningkatkan kemampuan membaca al-Qur'an dengan tartil dan benar, sehingga mempunyai implikasi positif terhadap penguasaan kompetensi membaca Al Qur'an sebagaimana yang menjadi salah satu kompetensi dasar pembelajaran mata pelejaran Pendidikan Agama Islam.

\section{Penutup}

Hasil yang dicapai dalam program pembelajaran Al Qur'an kepada para peserta didik SMP Bhakti Pertiwi Paiton Probolinggo melalui TPQ sekolah layak untuk dijadikan inspirasi bagi lembaga pendidikan lain untuk diimplementasikan juga di sekolahnya. Eksistensi TPQ sekolah dapat menjadi laboratorium Pendidikan Agama Islam (PAI), dimana peserta didik dapat mempraktekkan kompetensinya dalam hal membaca al-Qur'an, melaksanakan praktik salat, dan menerapkan sopan santun kepada guru dan sesama temannya. Apabila program ini telah tuntas dilaksanakan oleh siswa, maka TPQ sekolah dapat membuat program pasca TPQ, dengan membuat program tadarus al-Qur'an dan kajian tafsir al-Qur'an. Dengan demikian output lulusan sekolah mempunyai kompetensi dapat membaca al-Qur'an dengan tartil dan benar dan memahami makna ayat-ayat al-Qur' an yang dibaca tersebut. 


\section{DAFTAR PUSTAKA}

Abudin Nata. 2001. Manajemen Pendidikan Mengatasi Kelemehan Pendidikan Islam di Indonesia. Jakarta: Prenada Media.

Baharun, H. (2017a). Pengembangan Kurikulum; Teori dan Praktik (Konsep, Prinsip, Pendekatan dan Langkah-langkah Pengembangan Kurikulum PAI. Yogyakarta: CV Cantrik Pustaka.

Baharun, H. (2017b). Total Moral Quality: A New Approach for Character Education in Pesantren. Ulumuna, 21(1), 57-80.

H Baharun, A. M. (2011). Metodologi Studi Islam: Percikan Pemikiran Tokoh Dalam Membumikan Agama. Jogjakarta: Ar-Ruzz Media.

Hasan Baharun, Z. (2017). Manajemen Mutu Pendidikan: Ikhtiar dalam Meningkatkan Mutu Pendidikan Madrasah melalui Pendekatan Balanced Scorecard. Tulungagung: Akademia Pustaka.

Islam, S. (2017). Karakteristik Pendidikan Karakter; MenjawabTantangan Multidimensional Melalui Implementasi Kurikulum 2013, 1(1), 89-101.

Joko Susilo, M. 2007. Kurikulum Tingkat Satuan Pendidikan, Yogyakarta:Pustaka Belajar.

Khozin. 2006. Jejak-jejak Pendidikan Islam di Indonesia. Malang : UMM Press.

Saiful Syagala. 2005. Konsep dan Makna Pembelajaran, Bandung : Alfabeta.

Sadiman, A. 2006. Media Pendidikan. Jakarta : Raja Grafindo Persada.

Sanjaya, W. 2006. Pembelajaran Dalam Implementasi Kurikulum Berbasis Kompetensi. Jakarta : Kencana Prenada Media Group.

Thariq.2007.Mengapa-Harus-Qiro'ati, (http//pustakamawar.wordpress.com, diakses 9 Mei 2009).

Tohirin, 2005. Psikologi Pembelajaran Pendidikan Agama Islam. Jakarta : Raja Grafindo Persada.

Viannata, R. 2007. Pembelajaran Al Qur'an, (Online), (http//rara-banget.blogspot.com, diakses 9 Mei 2009). 